\title{
SAMĒRİGUMA PRINCIPA IZPRATNE UN PIEMĒROŠANA PUBLISKAJĀ IEPIRKUMĀ IESNIEGTA PIEDĀVĀJUMA IZVĒRTĒŠANĀ
}

\section{UNDERSTANDING AND APPLICATION OF PRINCIPLE OF PROPORTIONALITY IN EVALUATION OF A TENDER SUBMITTED IN PUBLIC PROCUREMENT}

\author{
Džeina Gaile, Mg. iur., LL.M. \\ Latvijas Universitātes Juridiskās fakultātes studiju programmas \\ "Tiesību zinātne" doktorante
}

\begin{abstract}
Summary
The principle of proportionality is one of the most important principles of public law, and it has been included amongst the public procurement principles in Directive 2014/24/EU. It requires that action undertaken must be proportionate to its objectives. In this article, the author explores the place of this principle in the public procurement field and application in the process of evaluation of a tender. It is concluded that this principle is both important when determining procurement requirements and evaluating tenders. For example, the contracting authority should not reject a tender for formal reasons. However, it can be difficult to evaluate whether this principle is complied with since in evaluation of tenders it is applied on a case-by-case basis.
\end{abstract}

Atslēgvārdi: publiskais iepirkums, samērīguma princips, piedāvājuma vērtēšana.

Keywords: public procurement, principle of proportionality, evaluation of tender.

\section{Ievads}

Raksta mērķis ir apskatīt samērīguma principa izpratni un piemērošanu publisko iepirkumu jomā, īpašu uzmanību pievēršot piedāvājuma vērtēšanas posmam. Tiek sniegts ieskats par šì principa vietu un nozīmi publisko iepirkumu sistēmā un tā būtiskākajiem piemērošanas aspektiem, aprakstot tā ietekmi uz prasību izvirzišanu un detalizētāk pievēršoties piemēriem, vērtējot piedāvājumu. Uzmanība tiek pievērsta aspektiem, kas var radīt sarežǵijumus, izvērtējot šì principa piemērošanas robežas. Apskatāmo jautājumu loks ir ierobežots, attiecinot to tikai uz Publisko iepirkumu likumu (turpmāk - PIL). Rakstā izmantota analītiskā, sistēmiskā, dogmatiskā un salīdzinošā pētniecỉbas metode.

${ }^{1}$ Publisko iepirkumu likums: LV likums. Pieņemts 15.12.2016. [15.01.2021. red.]. 


\section{Samērīguma principa nozīme un izpratne}

Samērīguma princips ir viens no administratīvajā procesā piemērojamiem vispārējo tiesību principiem ${ }^{2}$, kas atzìts par vienu no svarīgākajiem Eiropas Savienības (turpmāk - ES) ${ }^{3}$ un publisko tiesību principiem ${ }^{4}$. Tas attiecināms uz publisko iepirkumu jomu, jo iestādes darbības, sākot ar publiskā iepirkuma plānošanu līdz pat lēmuma paziņošanai, tiek îstenotas publisko tiesỉbu jomā $\overline{ }^{5}$.

Arī ar PIL pārṇemtās Direktīvas 2014/24/ES ${ }^{6}$ preambulas 1. apsvērumā norādīts, ka publisko līgumu slēgšanas tiesību piešķiršanai, ko īsteno dalībvalstu iestādes vai ko îsteno to vārdā, ir jāatbilst Līguma par Eiropas Savienības darbỉbu principiem un jo ìpaši brīvas preču aprites principam, brīvībai veikt uzṇēmējdarbību un pakalpojumu sniegšanas brīvībai, kā arī no tiem izrietošajiem principiem, proti, vienlīdzīgai attieksmei, nediskriminācijai, savstarpējai atzīšanai, proporcionalitātei un pārredzamībai, un kā viens no iepirkumu principiem direktīvas 18. pantā ir norādìts - "līgumslēdzējas iestādes [..] rìkojas samērīgi". Ši principa iekḷaušana pamatota ar to, ka ir iespējams ievērojami samazināt administratīvo slogu iepirkuma procedūrās, nodrošinoties, ka jebkuras procesuālas un būtiskas prasības ir samērīgas ar līguma priekšmetu. Lai uzsvērtu tā nozīmi, samērīguma princips ir tieši norādìts starp vispārējiem publisko iepirkumu principiem. ${ }^{7}$ Eiropas Savienības Tiesa (turpmāk - EST) šo principu piemēroja arī attiecībā uz Direktīvu 2004/18/EK, šì prakse būs vienlīdz nozīmīga, interpretējot 2014. gada direktīvu. ${ }^{8}$

Samērīguma principam ir svarīga nozīme visās procesa stadijās, it īpaši informācijas iegūšanas, administratīvā akta izdošanas un atcelšanas procesā. Jebkurā gadījumā, kad iestādei piešķirta rīcības brīvība, tās lēmumam un rīcībai jābūt samērīgai. Savukārt obligātā administratīvā akta gadỉjumā samērīguma princips pirmām kārtām jāievēro tiesību normas interpretēšanas procesā, it îpaši interpretējot tiesību normu, izmantojot sistēmisko un teleologisko metodi. ${ }^{9}$

Apskatot samērīguma principa vispārīgo izpratni, secināms, ka tā mērḳis ir ierobežot iestādes rīcības brīvību (diskrecionāro varu), nodrošinot, ka indivīda tiesības un intereses netiek ierobežotas vairāk, nekā tas nepieciešams, lai sasniegtu mērkki. ${ }^{10}$ Samērīguma princips noteic, ka tad, ja publiskā vara ierobežo personas tiesības un likumiskās intereses, ir jāievēro saprātīgs līdzsvars starp personas un

${ }^{2}$ Administratīvā procesa likums: LV likums. Pieņemts 25.10.2001., 4. panta pirmās daḷas 9. punkts. [25.01.2021. red.].

${ }^{3}$ Rezevska D. Vispārējo tiesību principu nozīme un piemērošana. 2. izd. Rīga: Daigas Rezevskas izdevums, 2015, 102. lpp.

${ }^{4}$ Briede J. (zin. red.). Administratīvā procesa likuma komentāri. A un B daḷa. Rīga: Tiesu nama ağentūra, 2013, 185.-186. lpp.

${ }^{5}$ Augstākās tiesas 23.05.2006. lēmums lietā SKA-306/2006, 10. p. Pieejams: http://at.gov.lv/downloadlawfile/4986 [aplūkots 03.02.2021.].

${ }^{6}$ Eiropas Parlamenta un Padomes Direktīva 2014/24/ES par publisko iepirkumu un ar ko atcel Direktīvu 2004/18/EK. Pieņemta 26.02.2014. [01.03.2021. red.].

7 Council of the European Union, "Proposal for a Directive of the European Parliament and of the Council on public procurement Cluster 8: Sound procedures" Council document 11266/12, p. 2. Pieejams: https://data.consilium.europa.eu/doc/document/ST-11266-2012-INIT/en/pdf [aplūkots 03.02.2021.].

${ }^{8}$ Arrowsmith S. The Law of Public and Utilities Procurement: Regulation in the EU and UK. $3^{\text {rd }}$ ed. London: Sweet and Maxwell, 2014, p. 631.

${ }^{9}$ Briede J. 2013, 190.-192. lpp.

${ }^{10}$ Turpat, 185.-186. lpp. 
valsts vai sabiedrības interesēm ${ }^{11}$. Arī EST norādījusi, ka samērīguma princips prasa, lai lïdzekḷ li, kurus pielieto, izmantojot Kopienu tiesību normu, būtu derīgi attiecīgā mērḳa īstenošanai un nepārsniegtu to, kas ir nepieciešams, lai to sasniegtu. ${ }^{12}$ Līdzīgi princips skaidrots Administratīvā procesa likuma (turpmāk - APL) 13. pantā. Pēc būtības samērīguma princips prasa, lai "veiktās darbības būtu samērīgas ar to mērķii"13 jeb "lai policija nešautu uz zvirbul̦iem ar lielgabaliem"14.

Jebkurā samērīguma izvērtējumā jāidentificē būtiskās intereses un tiek veikta svara vai vērtības piedēvēšana šìm interesēm, jo tas ir nepieciešams nosacijums pirms jebkuras izvērtēšanas. Parasti samērīguma pārbaudei būs trīs posmi - 1) vai lïdzeklis ir piemērots, lai sasniegtu mērķi, 2) vai tas ir nepieciešams, lai sasniegtu mērḳi, 3) vai lìdzekḷa radītais slogs indivīdam nebija nesamērīgs attiecībā pret mērḳi (samērīgums stricto sensu) ${ }^{15}$. Līdzīgi ir APL 66. pantā norādītie lietderības apsvērumi, kas faktiski ir vadlīnijas samērīguma principa ievērošanai ${ }^{16}$. Arī Satversmes tiesas izvērtējumā par tiesību normas atbilstību samērīguma principam tiek noskaidroti minētie apsvērumi, un, ja tiek atzīts, ka tiesību norma neatbilst kaut vienam no šiem kritērijiem, tad tā neatbilst arī samērīguma principam un ir prettiesiska. ${ }^{17}$

Publisko iepirkumu jomā ietvertas atsauces uz identisku samērīguma principa izpratni. ${ }^{18}$ Vispārējā tiesa norādijjusi, ka samērīguma princips prasa, lai iestāžu akti nepārsniegtu to, kas ir piemērots un nepieciešams izvirzīto mērḳu sasniegšanai, ar to saprotot, ka, ja ir iespēja izvēlēties vienu no vairākiem piemērotiem pasākumiem, jāizvēlas vismazāk apgrūtinošais un tā izraisītie trūkumi nedrīkst būt nesamērīgi ar sasniedzamajiem mērkiiem..$^{19}$

Kā redzams, šis princips līdzīgi tiek skaidrots gan ES, gan Latvijas kontekstā un, autores ieskatā, tā piemērotāiiem ir būtiski izprast iepriekš norādītos kritērijus. Tā kā vispārējo tiesỉbu principu saturs tiek noteikts ar konkretizācijas metodi ${ }^{20}$, tālāk apskatīta tā piemērošana publisko iepirkumu jomā.

\section{Samērīguma princips publisko iepirkumu jomā}

PIL neietver atsevišķu principu uzskaitījumu, pasūtītāja pienākums rīkoties samērīgi nav tieši noteikts arī 2. pantā pie likuma mērķiem. PIL ir tikai viena tieša norāde uz šo principu - pasūtitājs pēc iespējas dod priekšroku tādām prasībām, kritērijiem un noteikumiem, kas nodrošina iepirkuma atbilstîbu zaḷā

11 Satversmes tiesas 19.03.2002. spriedums lietā Nr. 2001-12-01, 3.1. p. Latvijas Vēstnesis, 2013, Nr. 33.

12 EST 14.12.2004. spriedums lietā C-210/03 The Queen, on the application of: Swedish Match AB and Swedish Match UK Ltd v. Secretary of State for Health, 47. p.

13 Tridimas T. General principles of EU Law. $2^{\text {nd }}$ ed. 2006, p. 136. Citēts pēc: Arrowsmith S. 2014, p. 628.

14 Fleiner F. Institutionen des deutschen Verwaltungsrechts, Tübingen: Mohr, 1928, s. 404. Citēts pēc: Mathews J. Proportionality Review in Administrative Law. In: Rose-Ackerman S., Lindseth P. L., Emerson B. (eds.). Comparative Administrative Law, $2^{\text {nd }}$ ed. Northampton: Edward Elgar Publishing, 2017 , p. 405.

15 Craig P., De Búrca G. EU law: Text, cases, and materials. $5^{\text {th }}$ edition. New York: Oxford University Press, 2011, p. 526.

16 Briede J. 2013, 637. lpp.

17 Satversmes tiesas 19.03.2002. sprieduma lietā Nr. 2001-12-01, 3.1. punkts. Latvijas Vēstnesis, 2013, Nr. 33.

18 Arrowsmith S. 2014, p. 628.

19 EST Vispārējās tiesas 10.12.2009. spriedums lietā T195/08 Antwerpse Bouwwerken NV v. European Commission, 57. p.; 20.09.2011. spriedums lietā T461/08 Evropaïki Dynamiki/EIB, 142. p.

${ }^{20}$ Rezevska D. 2015, 148. lpp. 
publiskā iepirkuma principiem, ievērojot samērīguma principu. ${ }^{21}$ Norādes uz nepieciešamību ievērot samērīgumu PIL pārsvarā iekḷautas saistībā ar prasību un iepirkuma noteikumu izvirzī̌sanu ${ }^{22}$. Augstākās tiesas (turpmāk - AT) ieskatā, par prasību samērīgumu pārbaudāms, vai attiecīgās kvalifikācijas prasības neietver ko tādu, kas pārsniedz saprātīgi nepieciešamo konkrētā iepirkuma mērķa sasniegšanai. ${ }^{23}$ Jo striktākas ir prasības, jo mazāk piegādātāji piedalīsies, un galu galā uz līgumu būs mazāka konkurence. Tādējādi samērīguma princips nodrošina, ka pieeja publiskiem līgumiem nav ierobežota, jo tas var tikt uzskatìts par iekšèjā tirgus ierobežojumu. ${ }^{24}$

EST samērīguma principu ir piemērojusi kā pamatu, lai ierobežotu izslēgšanas apjomu ${ }^{25}$, piemēram, kad dalībvalstis ir noteikušas nosacījumus, kas paredz piegādātāju izslēgt no iepirkuma procedūras ${ }^{26}$. Tomēr prof. S. Erousmita norāda, ka EST pieeja šajās lietās (Fabricom, Michaniki un sekojošās), kas prasa izvērtējumu katrā atsevišķā gadījumā, var tikt kritizēta, jo tā būtiski palielina iepirkumu procesa slogu, kā arī rada ievērojamu neskaidrību pasūtītājiem par to, vai konkrētos piegādātājus ir piel̦aujams izslēgt. Norādīto problēmu kontekstā nav iespējams teikt, ka katra konkrētā gadijjuma atsevišksa izvērtēšana ir piemērots alternatīvs līdzeklis, lai sasniegtu vienlīdzīgas attieksmes un pārskatāmības mèrķus. Turklāt rīcības brīvība, kuru paredz šāds atsevišķ gadījumu izvērtējums, ar diskrimināciju saistītu iemeslu dēl pati rada l̦aunprātīgas izmantošanas risku, jo padara iespējamus aizspriedumus gan nacionālajās, gan ES politikās.

G̣enerāladvokāta Ležē viedoklis Fabricom lietā ${ }^{27}$ atšḳīrās no tiesas viedokḷa, viņš uzskatīja, ka Beḷgijas plašais vispārīgais izslēgšanas noteikums ir attaisnojams ar nepieciešamību pēc tiesiskās drošibas un pārskatāmības. ${ }^{28} \mathrm{Kā}$ redzams, atšķiras viedokḷi par to, kāda nozīme piešķirama samērīguma un tiesiskās drošîbas principiem. Autores ieskatā, minētie riski attiecināmi arī uz citiem gadījumiem, kad piemērojams samērīguma princips, tajā skaitā uz turpmāk aprakstīto piedāvājumu vērtēšanas procesu.

\section{Samērīguma princips piedāvājuma vērtēšanā}

Vērtējot piedāvājumus, pasūtītājs atlasa un pārbauda piedāvājumus atbilstoši procedūras dokumentos noteiktajām prasībām un izvēlas piedāvājumu saskaṇā ar noteiktajiem piedāvājuma izvērtēšanas kritērijiem ${ }^{29}$. Jāṇem vērā, ka nolikums ir tiesību akts un tā noteikumi ir saistoši līdz pat brīdim, kad tiek izpildìts vai

21 PIL 19. panta pirmā dal̦a.

22 Sīkāk sk. PIL 13. panta piekto un sesto dal̦u, 20. panta otro daḷu, 41. panta otro daḷu u. c.

${ }^{23}$ Augstākās tiesas 27.08.2020. spriedums Nr. SKA-297/2020, 8. p. Pieejams: https://manas.tiesas.lv/ eTiesasMvc/nolemumi/pdf/420560.pdf [aplūkots 03.02.2021.].

${ }^{24}$ Hamer C. The possibility to exclude an economic operator that cannot be trusted. European Procurement \& Public Private Partnership Law Review, 2020, Vol. 15 (1), p. 50.

25 Arrowsmith S. 2014, 7-24, p. 628.

${ }^{26}$ EST 03.03.2005. spriedums apvienotajā lietā C-21/03 un C-34/03 Fabricom SA pret Beḷgijas valsti, EST 16.12.2008. spriedums lietā C-213/07 Michaniki AE pret Ethniko Symvoulio Radiotileorasis un Ypourgos Epikrateia.

${ }^{27}$ Ģenerāladvokāta F. Ležē 11.11.2004. secinājumi apvienotajā lietā C-21/03 un C-34/03 Fabricom SA pret Beḷgijas valsti.

28 Arrowsmith S. 2014, pp. 1293-1294.

29 PIL 41. panta pirmā daḷa. 
ir kḷuvis neapstrīdams lēmums par līguma slēgšanas tiesību piešķiršanu ${ }^{30}$. Visu pretendentu piedāvājumiem ir jāpiemēro vienādi nosacījumi, un tiem jābūt formulētiem skaidri, precīzi un nepārprotami. ${ }^{31} \mathrm{Lìdz}$ ar to, ja pasūtītājs, izmantojot rīcības brīvību, nolikumā ir noteicis konkrētas prasības, tam tās ir jāṇem vērā, izdodot administratīvo aktu par iepirkuma rezultātiem, un tam nav izvēles brīvības attiecībā uz administratīvā akta saturu ${ }^{32}$, pasūtītājam ir stingri jāievēro paša noteiktie kritēriji ${ }^{33}$. Tātad pasūtītājs, jau nosakot iepirkuma prasības, vispārīgi ir paredzējis savas turpmākās rīcības robežas. Tālāk apskatīti piemēri samērīguma piemērošanai piedāvājuma vērtēšanas gaitā.

Pasūtītājam, izstrādājot nolikumu, ir jādomā arī par to, vai veids, kādā pārliecināties par pretendenta spējām, nerada pārmērīgu slogu abām pusēm - pretendentam, pierādot kādu apstākli, un pasūtītājam, pārbaudot tā pastāvēšanu. ${ }^{34}$ Samērīguma princips ir būtisks, lai interpretētu direktīvas balansētā veidā, lai ierobežotu procesuālo slogu gan pasūtītājiem, gan piegādātājiem. ${ }^{35}$ Minētais saistāms, piemēram, ar PIL 41. panta astotajā daḷā paredzētajām tiesībām pieprasīt, lai tiek iesniegti piedāvāto preču paraugi, nepieprasot iesniegt tādu preču paraugus, kuru iesniegšana rada nesamērīgus izdevumus.

Samērīguma princips piemērojams arī, lai ierobežotu iespēju automātiski izslēgt neatbilstošu piedāvājumu, kad tas var tikt pieņemts, nekaitējot publisko iepirkumu noteikumu interesēm ${ }^{36}$. Regulējums piedāvājuma precizēšanai iekḷauts PIL 41. pantā un paredz arī samērīga termiṇa noteikšanu informācijas sniegšanai. Kā norāda profesore S. Erousmita, pastāv pienākums atsevišķos gadījumos pieḷaut kḷūdu labošanu piedāvājumā, pamatojoties uz samērīguma principu, ja labojumu nepiẹ̦aušana negatīvi ietekmētu konkurenci, bet neveicinātu nevienu nozīmīgu iepirkumu politikas mērḳi, kuru nevarētu sasniegt citos veidos. ${ }^{37}$ Attiecīgi PIL paredzētās pasūtītāja tiesības lūgt precizēt vai izskaidrot piedāvājumā ietverto informāciju Senāta praksē tiek saistītas ar nepieciešamību novērst pretendentu izslēgšanu vienīgi formālu iemeslu dēl un ievērot samērīguma principu. ${ }^{38}$ Piemēram, lietā, kur speciālista CV bija nepareizi norādīts tā apmeklēto kursu sertifikāta izdevējs, AT norādīja, ka automātiska izslēgšana no turpmākās dalības iepirkuma procedūrā, pamatojoties uz piemēroto normu, tikai nebūtiskas neprecizitātes (neuzmanības kḷūdas) dēḷ pretendenta iesniegtajā informācijā kvalifikācijas novērtēšanai būtu pārlieku formāla un neatbilstoša samērīguma principam. ${ }^{39} \mathrm{Uz}$ samērīgumu informācijas precizēšanas kontekstā norādījusi arī

\footnotetext{
30 Augstākās tiesas 17.08.2012. lēmums lietā Nr. SKA-850/2012, 7. p.

31 EST 02.06.2016. spriedums lietā C-27/15 Pippo Pizzo pret CRGT Srl, 36. p.

32 Augstākās tiesas 06.06.2017. spriedums lietā SKA-208/2017, 6. p. Pieejams: https://manas.tiesas.lv/eTiesasMvc/nolemumi/pdf/317091.pdf [aplūkots 04.02.2021.].

33 EST 10.10.2003. spriedums lietā C-336/12 Ministeriet for Forskning, Innovation og Videregående Uddannelser pret Manova A/S, 40. p.

34 Augstākās tiesas 21.05.2018. lēmums lietā Nr. SKA-1222/2018, 16. p. Pieejams: https://manas.tiesas.lv/ eTiesasMvc/nolemumi/pdf/354871.pdf [aplūkots 04.02.2021.].

35 Arrowsmith S. 2014, p. 628.

36 Ibid.

37 Ibid., p. 823.

38 Latvijas Republikas Augstākās tiesas Tiesu prakses apkopojums publisko iepirkumu lietās (2005. gada februāris - 2020. gada jūnijs). Pieejams: http://at.gov.lv/lv/tiesu-prakse/tiesu-prakses-apkopojumi/administrativas-tiesibas [aplūkots 02.03.2021.].

39 Augstākās tiesas 16.07.2010. spriedums lietā SKA-296/2010, 11., 12. p. Pieejams: http://at.gov.lv/ downloadlawfile/472 [aplūkots 02.03.2021.].
} 
Vispārīgā tiesa. ${ }^{40}$ Profesores S. Erousmitas ieskatā, visdrīzāk dalībvalsts nevar aizliegt piedāvājuma precizēšanu, kad to pieprasa samērīguma princips, un var apgalvot, ka pienākumu labot piedāvājumu, kas tiek piemērots saskaṇā ar ES samērīguma principu, vispārīgi nevar aizstāt ar pretējiem nosacījumiem iepirkuma dokumentos. ${ }^{41}$

Samērīguma princips ņemams vērā arī gadījumos, kad tiek izvērtēta pretendenta izslēgšanas iespēja, piemēram, izvēles (fakultatīvu) izslēgšanas nosacījumu gadỉjumā. EST izskatīja lietu, kurā Nīderlandes tiesības paredzēja iespēju izslēgt pretendentu, ja tas ir vainīgs smagā profesionālās ètikas pārkāpumā, un secināja, ka, tā kā iepirkuma dokumentācijā bija norāde, ka piedāvājumi tiks noraidìti, neveicot samērīguma izvērtējumu, kas varēja radīt nedrošību ieinteresētajiem piegādātājiem (jo īpaši no citām dalībvalstīm), konkrētajā gadījumā vienlīdzīgas attieksmes un pārskatāmības principu kontekstā pasūtītājs nebija tiesīgs šādu piegādātāju nenoraidīt. ${ }^{42}$ Novērtējums, kas attiecas uz to, vai pasūtītājs uzticas konkrētajam piegādātājam, ir balstīts uz lielu rīcības brīvību - brīvību, kas ir jāizmanto atbilstoši ES iepirkumu principiem attiecībā uz pārskatāmību, vienlīdzīgu attieksmi un, visbūtiskāk, samērīguma principu ${ }^{43}$. Tā kā Saeimā 1. lasījumā ir pieņemti grozījumi PIL izslēgšanas noteikumos, kas saistīti ar iespēju apšaubìt pretendenta godprātību ${ }^{44}$, minētie aspekti var kḷūt ìpaši aktuāli.

Iepriekš norādītajā EST spriedumā vienlīdzīgas attieksmes un pārskatāmības princips tika uzskatīts par būtiskāku nekā samērīguma izvērtējums, lai arī ir autori, kuru ieskatā samērīguma princips kā vispārīgais princips būtu piemērojams arī gadījumā, kad ir norādīts, ka tas netiks piemērots ${ }^{45}$. Autore uzskata, ka šāda situācija tomēr radītu risku tiesiskajai drošībai. Tomēr lēmumu ietekmē konkrētās situācijas apstākḷi un var būt dažādi viedokḷi par to, kas katrā gadỉjumā ir samērīgi.

Tā kā samērīgumu nav iespējams izvērtēt, n̦emot vērā tikai objektīvos kritērijus, subjektivitāte ir viena no samērīguma principa iezīmēm un pilnīgi iespējams, ka, lemjot par vienu un to pašu jautājumu, dažādas iestādes vai dažādi tiesneši dažādās tiesās var nonākt pie dažādiem secinājumiem ${ }^{46}$, kas var radīt pamatu strīdiem. Kā norāda J. Briede, lai novērstu manipulācijas ar samērīguma principu, ir l̦oti svarīgi, lai apsvērumi, kas izdarīti, piemērojot samērīguma principu, tiktu atspoguḷoti administratìvajā aktā vai tiesas nolēmumā. ${ }^{47}$

Autores ieskatā, norādītie piemēri, kuros pasūtītājam jāṇem vērā samērīguma princips, parāda, cik būtiska ietekme uz iepirkuma rezultātu var būt šì

\footnotetext{
${ }^{40}$ EST Vispārējās tiesas 27.09.2002. spriedums lietā T-211/02 Tideland Signal Ltd v. Commission of the European Communities; EST Vispārējās tiesas 10.12.2009. spriedums lietā T195/08 Antwerpse Bouwwerken NV v. European Commission.

41 Arrowsmith S. 2014, pp. 831, 834.

42 EST 14.12.2014. spriedums lietā C-171/15 Connexxion Taxi Services BV pret Staat der Nederlanden Ministerie van Volksgezondheid, Welzijn en Sport u. c.

43 Hamer C. 2020, p. 43.

${ }^{44}$ Likumprojekta "Grozijumi Publisko iepirkumu likumā” 5. punkts un anotācija. Pieejams: https://titania. saeima.lv/LIVS13/saeimalivs13.nsf/0/5CC1C6D87B5BA749C2258616004DC062?OpenDocument [aplūkots 03.02.2021.].

45 Hamer C. 2020, p. 50.

${ }^{46}$ Gerapetritis G. Proportionality in Administrative Law. Judicial Review in France, Greece, England and in the European Communitu. Athens: Ant. N. Sakkoulas Publishers, 1997, p. 257. Citēts pēc: Briede J. 2013, 192. lpp.

47 Briede J. 2013, 192. lpp.
} 
principa izpratnei, kā arī to, kādi ir potenciālie sarežǵījumi samērīguma principa piemērošanā.

\section{Kopsavilkums}

1. Samērīguma princips ir vispārējo tiesību princips, kas ir būtisks gan ES, gan nacionālajā līmenī un ir piemērojams arī publisko iepirkumu jomā.

2. Ar Direktīvas 2014/24/ES pieņemšanu samērīga rīcība ir tieši nostiprināta kā viens no iepirkumu principiem, savukārt PIL šāda vispārīga norāde nav konstatējama.

3. Saturiski samērīguma princips prasa, lai pasūtītāja rīcība ir samērīga ar tās mērķi, un tas parasti tiek pārbaudīts, izvērtējot piemērotību, nepieciešamību un samērīgumu.

4. Publisko iepirkumu gadījumā samērīgums visbiežāk tiek saistīts ar norādi, ka prasībām ir jābūt samērīgām ar līguma priekšmetu, savukārt vērtēšanas procesā samērīgums ir būtisks, piemēram, lai nodrošinātu, ka piedāvājums netiek noraidìts tikai formālu vai nebūtisku iemeslu dēḷ.

5. Samērīguma principa piemērošanu piedāvājumu vērtēšanas laikā apgrūtina tas, ka izvērtējums veicams katrā atsevišksā gadījumā un šì principa piemērošana nevar izslēgt subjektivitāti, tādēḷ îpaši būtisks ir izsvērts lēmuma pamatojums. 